\title{
Direct and residual effects of phosphorus from organic manures and single super phosphate on microbial population and biomass carbon content in groundnut- sunflower cropping system
}

\author{
Punitha Premanandarajalh and A. Raja Rajan \\ Tamil Nadu Agricultural University, Coimbatore, India
}

\begin{abstract}
Potculture experiments were conducted using different phosphorus sources at Tamil Nadu Agricultural University, Coimbatore, during 2007 - 2008, to improve organic carbon content and to maintain a better microbial population in groundmut (Arachis hypogaea L) sunflower (Helianthus annuus L) cropping system. Four organic sources (farmyard manure, poultry manure, vermicompost and sewage sludge) evaluated in comparison with the standard inorganic source of single superphosphate, all applied on equal P basis@34 $\mathrm{kg} \mathrm{P}_{2} \mathrm{O}_{5}$ hat. The six treatments, including a no-P control were replicated four times in a completely randomized design. The main crop of groundnut (VRI 2) was followed by the residual crop of sunflower (Co 4). Post-harvest soil analysis was carried out after groundnut and sunflower: Organic manures increased the organic carbon content, biomass carbon content and micrubial population. Poultry manure significantly increased the microbial population and biomass carbon content in main and residual cropping than single supper phosphate. However, the microbial biomass carbon content in the post-residual crop soil was lower than that in the post-harvest soil after first crop.
\end{abstract}

Keywords: Biomass carbon, microbial population, organic carbon, organic manure, phosphorus source

\section{Introduction}

Organic manures play a vital role in maintenance of physical, chemical and biological conditions of soil and supply macro and micronutrients to crops, besides maintaining humic substances in soil (Sharma, 1992). The judicious combination of organic manures and fertilizers should be used for improving crop productivity and maintaining soil fertility (Dikshit and Khatik, 2002).

The soil is crowded with millions of living organisms which make it a living and a dynamic system. These organisms not only help in the development of soils but also carry out a number of transformations and facilitating the availability of nutrients to the plants. In a long term soil management farmyard manure (FYM) increased microbial biomass content in soil Kandeler et al. (1999). Organic manures increase soil respiration and levels of soluble organic carbon and microbial biomass carbon by a factor of 2 to 3 compared with the control (Rochette and Gregorich, 1998).

The energy (food) requirements of soil are provided by soil organic matter and reduced substances get continuously added to it. Soil organic carbon changed significantly with the addition of organic manures after a three-year period, but not with inorganic fertilization, in a groundnut-based cropping system (Subrahmaniyan et al., 1999).

Organic manures also have a pronounced residual effect on soil property. Residual effect of long term use of fertilizers alone and in combination with FYM had a significant improvement in soil properties Babhulkar et al. (2000). This present study was carried out to study the impact of different organic manures on soil microbial population in post harvest soil after main and residual crop.

\section{Materials and Method}

The soil used in the present study was collected from the farm of Regional Research Station, Vriddhachalam, Cuddalore District, Tamil Nadu. The content of organic carbon was $6.3 \%$. The soil texture was loamy sand.

The processed soil samples were filled in earthen pots at the rate of $8 \mathrm{~kg}$ soil per pot. There were 
four organic sources (farmyard manure, poultry manure, vermicompost and sewage sludge) evaluated in comparison with the standard inorganic source of single superphosphate, all applied on equal $\mathrm{P}$ basis at the rale of $34 \mathrm{~kg} \mathrm{P}_{2} \mathrm{O}_{5}$ $\mathrm{ha}^{-1}$. The six treatments, including a no-P (control) were replicated four times in a completely randomized design making a total of 24 pots.

Seeds of groundnut (five per pot) were sown in each pot. To all the pots, common basal applications of urea, muriate of potash and gypsum were given. Routine cultural practices were adopted in raising the crop. After the harvest of main crop groundnut, the soil in the pots were removed, gently powdered and repotted again. Common basal applications of urea and muriate of potash were given; no phosphorus was applied. Seeds of sunflower were then sown in each pot. Routine cultural practices were followed in raising the crop. Post-harvest soil analysis for organic carbon content, biomass carbon content and microbial population viz. bacteria, fungi and actinomycetes were carried out after groundnut and sunflower.

\section{Statistical analysis}

The data obtained from the above investigations were subjected to statistical analysis following the methods to find out the effect of various treatments on organic carbon content, biomass carbon content and microbial population in soil after groundnut and sunflower (Panse and Sukhatme, 1967)

\section{Results and Discussion}

\section{A. Main effect of phosphorus source}

\section{Soil organic carbon content in post- harvest soil after groundnut}

Phosphorus application significantly increased the soil organic carbon content. Among the phosphorus sources, poultry manure was foremost $(7.2 \%)$. Superphosphate treated soil recorded the lowest organic carbon content $(5.7 \%)$ and was significantly higher than control (Figure 1).

Organic carbon contents of soil were significantly improved with different phosphorus sources than control. The increase in organic carbon content might be due to the addition of organic manures which stimulated the growth and activity of microorganisms, and also due to better root growth. These observations are in line with the findings of Varalakshmi et al. (2005) in groundnut - finger millet cropping sequence. Organic carbon content was also high in inorganic phosphorus (single superphosphate) treated soil. This might be due to the improvement in root and shoot growth. Higher production of biomass might have increased the organic carbon content (Babinulkar et al., 2000). Poultry manure is rich organic manure since solid and liquid excreta are excreted together resulting in no urine loss (Mohamed Amanullah et al., 2007).

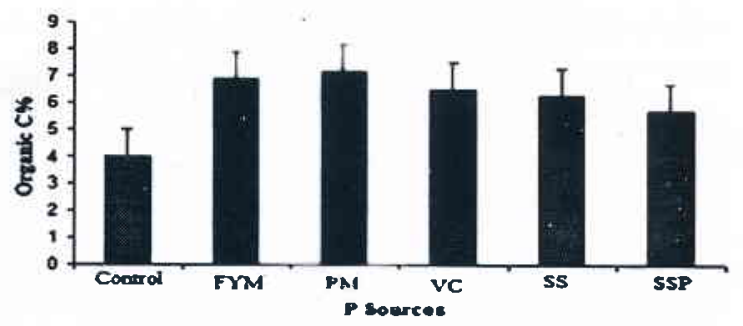

Figure 1. Effect of phosphorus sources on soil organic carbon content after groundnut. (FYM: Farmyard Manure, P: Phosphorus, PM: Poultry manure, SS: Sewage sludge, SSP: Superphosphate, VC: Vermicompost

\section{Microbial population and biomass carbon in post-harvest soil after groundnut}

\section{a. Microbia population}

The data on microbial population in post-harvest soil indicated that the maximum population of bacteria, fungi and actinomycetes (36 cfu x $10^{\circ} \mathrm{g}$ ', $11 \mathrm{cfu} \times 10^{4} \mathrm{~g}^{-1}$ and $28 \mathrm{cfu} \times 10^{3} \mathrm{~g}^{-1}$, respectively) was in the poultry manure treated soil. Among the organic manures, sewage sludge treatment recorded the lowest microbial population, but this was significantly higher than that in chemical fertilizer treatment (Table 1). The high organic carbon content in soil applied with poultry manure might have stimulated the microorganisms by serving as source of carbon, energy and other nutrients essential for their growth and multiplication, and thus increased the soil activities in poultry manure treatment. Similar results of increased enzyme activity due to poultry manure application have been reported by Boomiraj (2003) in Bhendi. 
Table 1: Effect of phosphorus sources on microbial population and biomass carbon content

\begin{tabular}{lcccc}
\hline Phosphorus sources & $\begin{array}{c}\text { Biomass carbon } \\
\left(\mathrm{mg} \mathrm{kg} \mathrm{kg}^{-1}\right)\end{array}$ & $\begin{array}{c}\text { Bacteria } \\
\left(\mathrm{cfu} \times 10^{6} \mathrm{~g}^{-1}\right)\end{array}$ & $\begin{array}{c}\text { Fungi } \\
\left(\mathrm{cfu} \times 10^{4} \mathrm{~g}^{-1}\right)\end{array}$ & $\begin{array}{c}\text { Actinomycetes } \\
\left(\mathrm{cfu} \times 10^{3} \mathrm{~g}^{-1}\right)\end{array}$ \\
\hline Control & $164 \mathrm{~d}$ & $13.0 \mathrm{f}$ & $4.0 \mathrm{~d}$ & $11.0 \mathrm{~d}$ \\
Farmyard manure & $315 \mathrm{a}$ & $30.0 \mathrm{~b}$ & $9.0 \mathrm{~b}$ & $24.0 \mathrm{ab}$ \\
Poultry manure & $325 \mathrm{a}$ & $36.0 \mathrm{a}$ & $11.0 \mathrm{a}$ & $28.0 \mathrm{a}$ \\
Vermicompost & $311 \mathrm{a}$ & $25.0 \mathrm{c}$ & $7.0 \mathrm{c}$ & $21.0 \mathrm{bc}$ \\
Sewage sludge & $258 \mathrm{~b}$ & $21.3 \mathrm{~d}$ & $6.0 \mathrm{c}$ & $19.0 \mathrm{c}$ \\
Superphosphate & $190 \mathrm{c}$ & $18.0 \mathrm{e}$ & $4.0 \mathrm{~d}$ & $14.0 \mathrm{~d}$ \\
\hline P value & $<0.05$ & $<0.05$ & $<0.05$ & $<0.05$ \\
\hline
\end{tabular}

(cfu: colony forming units). Mean followed by the same letters in each column are not significantly different at $\mathrm{p}<0.05$ according to DMRT.

\section{b. Biomass carbon}

The microbial biomass carbon content in postharvest soil was higher in poultry manure treated soil and was comparable with farmyard manure treatment ( 325 and $315 \mathrm{mg} \mathrm{kg}^{-1}$ respectively). This was followed by vermicompost treated soil. Single superphosphate treatment recorded the lowest value for biomass carbon among the phosphorus sources, though significantly superior to control (Table 1). Increased amount of microbial biomass was due to the amendment of soil with different organic sources. Increase in microbial biomass carbon content in poultry manure and farmyard manure treated soil might be due to the increased availability of water-soluble carbon and nutrients, which stimulated microbial growth. This view was confirmed by Zaman et al. (2002). There was a significant correlation between organic carbon content and biomass carbon content in soybeanwheat cropping sequence with farmyard manure application Manna et al. (1996). Increase in microbial biomass carbon in enriched soil could be attributed to the easily available biodegradable in the soil which stimulated the biomass (Bhattacharrya et al., 2001).

\section{B. Residual effect of phosphorus sources}

\section{Soil organic carbon content in post- harvest soil after sunflower}

Statistical analysis showed that the organic carbon content was higher in farmyard manure treated $(4.9 \%)$ soil and that was on par with poultry manure $(4.5 \%)$ and sewage sludge $(4.6 \%)$ treatments. In vermicompost treatment, organic carbon content was $4.0 \%$ which was on par with poultry manure and sewage sludge treatments (Figure 2).

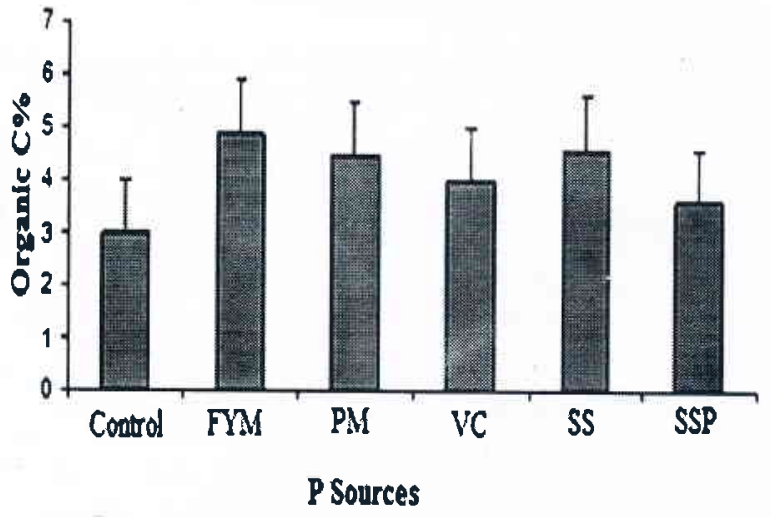

Figure 2. Effect of phosphorus sources on soil organic carbon content after sunflower. (P: Phosphorus, PM: Poultry manure, FYM: Farmyard Manure, VC: Vermicompost, SS: Sewage sludge, SSP: Superphosphate)

The results of the present investigation revealed that the organic carbon content was higher in organic manure treated soil than in the chemical fertilizer treatment and control. It might be postulated that more production of biomass and their subsequent decomposition have contributed towards improving the organic carbon status of the soil (Chahal et al., 1984). The organic carbon content was lower in soil after the harvest of residual crop (sunflower) than the first crop (groundnut). This may be due to the decomposition of organic manure added. This result draws support from the work of Singh et al. (2001). Results of a long-term experiment indicated that there had been a decline in organic carbon status on application of fertilizers (Swarup, 1999). 


\section{Microbial population and biomass carbon in post-harvest soil after sunflower}

\section{a. Microbial population}

The results pertaining to the residual microbial population indicated that as in microbial population in soil after the main crop of groundnut, the highest bacteria, fungi and actinomycetes population was recorded in poultry manure treated soil $(27 \mathrm{cfu} x$ $10^{6} \mathrm{~g}^{-1}, 9 \mathrm{cfu} \times 10^{4} \mathrm{~g}^{-1}$ and $25 \mathrm{cfu} \times 10^{3} \mathrm{~g}^{-1}$, respectively). The population was lower in residual soil than the soil after the first crop (Table 2). The data on microbial population indicated that organic sources increased the microbial population more than the inorganic treatments.
Among the organic sources, poultry manure increased the microbial population significantly in reidual soil. Higher population of microbes under " "ganic treatments acted as an index of soil fertility because it serves as temporary sink of nutrients flux as observed by Hassink et al. (1991). The lowest microbial load was due to inorganic fertilizers which might be due to the inhibitory nature of chemical fertilizers on the growth and development of microbes. This was supported by Leka et al., 2011. Poultry manure addition to rice increased the bacteria, fun actinomycetes population as well as dehydrogenase, urease, and phosphatase activities (Yadav and Christopher, 2007).

Table 2. Effect of phosphorus sources on microbial population and biomass carbon content

\begin{tabular}{lcccc}
\hline Phosphorus source & $\begin{array}{c}\text { Biomass carbon } \\
\left(\mathrm{mg} \mathrm{kg}^{-1}\right)\end{array}$ & $\begin{array}{c}\text { Bacteria } \\
\left(\mathrm{cfu} \times 10^{\mathrm{b}} \mathrm{g}^{-1}\right)\end{array}$ & $\begin{array}{c}\text { Fungi } \\
\left(\mathrm{cfu} \times 10^{-} \mathrm{g}^{-1}\right)\end{array}$ & $\begin{array}{c}\text { Actinomycetes } \\
\left(\mathrm{cfu} \times 10^{\mathrm{3}} \mathrm{g}^{-1}\right)\end{array}$ \\
\hline Control & $118^{\mathrm{e}}$ & $10.0^{\mathrm{b}}$ & $3.0^{\mathrm{b}}$ & $10.0^{\mathrm{d}}$ \\
Farmyard manure & $290^{\mathrm{ab}}$ & $23.0^{\mathrm{b}}$ & $7.0^{\mathrm{b}}$ & $18.0^{\mathrm{c}}$ \\
Poultry manure & $304^{\mathrm{a}}$ & $29.0^{\mathrm{a}}$ & $9.0^{\mathrm{a}}$ & $25.0^{\mathrm{a}}$ \\
Vermicompost & $272^{\mathrm{b}}$ & $22.0^{\mathrm{b}}$ & $8.0^{\mathrm{a}}$ & $22.0^{\mathrm{ab}}$ \\
Sewage sludge & $238^{\mathrm{c}}$ & $27.0^{\mathrm{a}}$ & $7.0^{\mathrm{a}}$ & $19.0^{\mathrm{bc}}$ \\
Superphosphate & $154^{\mathrm{d}}$ & $14.0^{\mathrm{c}}$ & $4.0^{\mathrm{b}}$ & $16.0^{\mathrm{c}}$ \\
\hline Pvalue & $<0.05$ & $<0.05$ & $<0.05$ & $<0.05$ \\
\hline
\end{tabular}

Mean followed by the same letters in each column are not significantly different at $p<0.05$ according to DMRT.

\section{b. Biomass carbon}

Microbial biomass carbon content in the residual soil was:lower than the post-harvest soil after first crop. But there was a significant influence on biomass carbon content by different treatments. Among treatments, poultry manure exerted the highest content: That was followed by farmyard manure treatment (Table 2). Organic manure treatment increased the biomass carbon content in residual soil and the increase was higher in poultry manure treated soil. This was probably due to higher availability of substrate as carbon from applied organic manures, intense rooting activity and better soil water status. Increased availability of water-soluble carbon and nutrients might stimulate microbial growth (Patra et al., 1992).

\section{Conclusions}

Biomass carbon content was higher in organic manure treated soil than in control but. it was lower in residual soil than the post-harvest soil after first crop. Among the phosphorus sources, poultry manure exhibited the greatest influence. The microbial population and organic carbon carbon content was also higher in poultry manure treated soil. Among the phosphorus sources tried, poultry manure was the best source in increasing postharvest soil microbial population and biomass carbon content in main and residual crop.

\section{References}

Babhulkar, P.S., R.M. Wandile., W.P. Badole and S.S. Balpande (2000). Residual effect of long-term application of farmyard manure and fertilizers on soil properties and yield of soybean. Journal of Indian Society of Soil Science 48 (1): 89-92.

Bhattacharya, P., K. Chakrabarti., A. Chakraborty and B. Bhattacharya (2001). Microbial biomass and activities of soils amended with municipal solid waste compost. J. Indian. Soci. Sorl Sici., 49 (1): 98-104. 
Boomiraj, K. (2003). Evaluation of organic sources of nutrients, panchagavya and botanicals spray on bhendi (Abelmo schus esculentus Moench.) M. Sc. Thesis, Tamil Nadu Agric. Univ., Coimbatore.

Chahal, R.S., J.P. Singhand A.P. Khera (1984). Cumulative, direct and residual effect of phosphorus, potassium and FYM on crop yield and soil characteristics. Journal of

Dikshit, P.R. and S.K. Khatik (2002). Influence of organic manures in combination with chemical fertilizers on production, quality and economic feasibility of soybean in Typic Haplustert of Jabalpur. Legume Research 25 (1): 53-56.

Hassink, J., G. Lebbink and J.A. Van Veena (1991). Microbial biomass and activity of a reclaimed - polder soil under a conven tional or a reduced - input farming system. Soil Biology and Biochemistry 23: 507513.

Kandeler, E., M. Stemmer and E. Klimanek (1999). Response of soil microbial biomass urease and xylanase within particle size fractions to long-term soil Inanagement. Soil Biology and Bioch emistry 31: 261-273.

Leka, M., D. Dragutin., B. Ilinka., J. Zoran., P.C. Marijana and S. Vladeta, S (2011). Effect of different fertilizers on the microbial activity and productivity of soil under potato cultivation African Journal of Biotecnology 10 (36): 6954-6960.

Manna, M.C., S. Kundu., M. Singh and P.N. Takkar (1996). Influence of farmyard

- manure on dynamics of microbial biomass and its turn over and activity of enzymes under a soybean-wheat system on a Typic Haplustert. Journal of Indian Society of Soil Science 44 (3): 409-412.

Mohamad Amanullah, M., E. Somasundaram., K. Vaiyapuri and K. Sathyamoorthi (2007). Poultry manure to crops - A review. Agricultural Review., 28 (3): 216-222.

Panse, V.C. and P.V. Sukhatme (1967). Statistical Methods for Agricultural Workers, ICAR, New Delhi.
Patra, D.D., S.C. Bhandri and A. Misra (1992). Effect of plant residue on the size of microbial biomass and nitrogen minerali zation in soil. Incorporation of cowpea and wheat straw. Soil Science and Plant Nutrition 38 (1): 1-6.

Rochette, R. and E.G. Gregorich (1998). Dyna mics of soil microbial biomass carbon, soluble organic carbon and carbondioxide evolution after three years of manure application. Canadian Journal of Soil Science 78: 283-290.

Sharma, R.A. (1992). Efficient water use and sustainable production of rainfed soybean and safflower through conjunctive use of organics and fertilizer. Crop Research 5: 181-194.

Singh, M., V.P. Singh and K. Sammi Reddy (2001). Effect of integrated use of fertilizer nitrogen and farmyard manure or green manure on transformation of nitrogen, potassium, sulphur and produ ctivity of rice wheat system on a Vertisol. Journal of Indian Society of Soil Science 47: 72 .

Subrahmaniyan, K., P. Kalaiselvan and N. Arulmozhi (1999). Nutrition management in groundnut based cropping system. Legume Research 22 (2): 124-126.

Swarup, A. (1999). Integrated nutrient supply and management system for sustained crop production in alkali soils. Fertilizer NÉws 38: 27-34.

Varalakshmi, L.R., C.A. Srinivasamurthy and S. Bhaskar (2005). Effect of integrated use of organic manures and inorganic fertilizers on organic carbon, available nitrogen, phosphorus and potassium in sustaining productivity of groundnutfinger millet cropping system. Journal of Indian Society of Soil Science 52 (3): 315-318.

Yadav, B.K. and L.A. Christopher (2007). Effect of organic manures applied to rice crop on microbial population and enzyme activity in post harvest soil. Journal of Ecobiology 20 (2): 139-144.

Zaman, M.D., H.J. Sakmoto., S. Goto and K. Inubushi (2002). Effect of sewage sludge compost and chemical fertilizer applica tion on microbial biomass and nitrogen mineralization rates. Soil Science and Plant Nutrition 48: 195-201. 